\title{
Response of rice cultivars to nitrogen in upland conditions
}

\author{
Fábio Luiz Checchio Mingotte ${ }^{1}$, Renata Kimie Hanashiro ${ }^{2}$, Domingos Fornasieri Filho ${ }^{3}$
}

\begin{abstract}
Against the background of a growing world population, rice (Oryza sativa L.) consumption is expected to grow faster than its production. Therefore, an appropriate question would be: how to increase productivity in the shortterm? In this respect, it becomes important the implementation of modern agricultural production systems, such as upland rice with supplemental sprinkler irrigation. Additional information is needed to maximize the available resources, with special attention given to research on the use of nitrogen. This study aimed to evaluate the agronomic performance of commercial rice cultivars with different plant characteristics in upland conditions with supplemental sprinkler irrigation, when subjected to nitrogen in topdress application at the $\mathrm{R}_{1}$ stage (panicle differentiation). The experiment was arranged in a randomized block with split plot design, with 65 treatments, consisting of the combination of 13 cultivars in the plots, and five nitrogen levels in the subplots $\left(0,40,80,120\right.$ and $\left.160 \mathrm{~kg} \mathrm{ha}^{-1}\right)$, with four replications. Genetic variability was detected among rice cultivars and the agronomic performance in response to the applied nitrogen. The topdressing application of nitrogen increases, in general, the production components and grain yield in rice. Cultivars BRS Primavera, Caiapó and IAC 202 stood out for grain yield, followed by Baldo, Carnaroli, BRS Curinga and IAC 500 with lower yields.
\end{abstract}

Key words: Oryza sativa L., nitrogen rates, sprinkler irrigation, yield components, grain yield.

\section{RESUMO}

\section{Resposta de cultivares de arroz ao nitrogênio em condições de terras altas}

No cenário crescente da população mundial, a cultura do arroz (Oryza sativa L.) apresenta projeções de consumo superiores às da sua produção. Um questionamento oportuno seria: em curto prazo como aumentar a produtividade? Neste aspecto, torna-se importante a implantação de modernos sistemas agrícolas de produção, a exemplo do arroz em terras altas, sob condições de irrigação suplementar por aspersão. Informações adicionais são necessárias para maximizar os recursos disponíveis, destacando-se as pesquisas que se relacionam com o uso do nitrogênio. Este trabalho teve por objetivo avaliar o comportamento agronômico de cultivares comerciais de arroz, com características distintas de planta, em condições de terras altas, sob irrigação suplementar por aspersão, quando submetidas a doses de nitrogênio aplicadas em cobertura, no estádio $\mathrm{R}_{1}$ (diferenciação da panícula). O delineamento estatístico foi o de blocos casualizados, com parcelas subdivididas, com 65 tratamentos, constituídos pela combinação de 13 cultivares nas parcelas, e cinco doses de nitrogênio nas subparcelas $\left(0,40,80,120\right.$ e $\left.160 \mathrm{~kg} \mathrm{ha}^{-1}\right)$, com quatro repetições. Observouse a existência de variabilidade genética entre os cultivares de arroz e no comportamento agronômico frente ao nitrogênio aplicado. A aplicação do nitrogênio em cobertura incrementa, de forma geral, os componentes produtivos e a produtividade de grãos do arroz. Quanto à produtividade de grãos, destacam-se os cultivares BRS Primavera, Caiapó e IAC 202, seguidos por Baldo, Carnaroli, BRS Curinga e IAC 500 como os de menores produtividades.

Palavras-chave: Oryza sativa L., doses de nitrogênio, irrigação por aspersão, componentes de rendimento, produção de grãos.

\footnotetext{
Received: 08/12/2011: Accepted: 02/01/2013.

${ }^{1}$ Agronomist Engineer, Master of Science. Departamento de Produção Vegetal, Universidade Estadual Paulista, Contact via Prof. Paulo Donato Castellane, s/n, 14884-900, Jaboticabal, São Paulo, Brasil. flcmingotte @ gmail.com (corresponding author)

${ }^{2}$ Agronomist Engineer. Departamento de Produção Vegetal, Universidade Estadual Paulista, Contact via Prof. Paulo Donato Castellane, s/n, 14884-900, Jaboticabal, São Paulo, Brasil. rehanashiro@gmail.com

${ }^{3}$ Agronomist Engineer, Doctor of Science. Departamento de Produção Vegetal, Universidade Estadual Paulista, Contact via Prof. Paulo Donato Castellane, s/n, 14884-900, Jaboticabal, São Paulo, Brasil. fornasieri@fcav.unesp.br
}

Rev. Ceres, Viçosa, v. 60, n.1, p. 086-095, jan/fev, 2013 


\section{INTRODUCTION}

The world production of processed rice in the agricultural year 20010/11, around 452.4 million tons, was only enough to meet the current demand of 451.2 million tons (USDA, 2011). Considering the world population of about seven billion people in 2011, with the projection to reach eight billion in 2020, it is estimated to be necessary to add to the rice market about ten million tons/year to meet the future demand. It is unlikely that increases in the cultivated area and yield of rice will occur because of the stability of the crop maintained in the world since 1980. The Asian continent, which accounts for most of the production and consumption worldwide, has no availability to create new agricultural lands in the flooded system, where yields are relatively high (Fornasieri Filho \& Fornasieri, 2006). Latin America stands out as the only region with potential to increase rice production and meet the future demand. Brazil, at present, contributes $1.85 \%$ of world production and is the largest producer among the South American countries, accounting for $55 \%$ of the production (Yokoyama et al., 1999). In the agricultural year 2010/11, rice occupied a total area of 2,746.7 hectares, of which approximately 50\% with lowland rice using controlled irrigation. As the production per unit area of lowland rice $\left(5,583 \mathrm{~kg} \mathrm{ha}^{-1}\right)$ is higher than that produced in upland conditions $\left(1,472 \mathrm{~kg} \mathrm{ha}^{-1}\right)$, the irrigated system contributed $78.4 \%$ of the total production in the country (12,628.2 tons) (CONAB, 2011).

Lowland rice is grown primarily in the Rio Grande do Sul and Santa Catarina, accounting for 47.3 and $73.8 \%$ of the cultivated area, respectively, and the domestic production (CONAB, 2011). These states have no availability to create new agricultural lands for lowland rice production. Considering the whole country, lowland rice could be cultivated in flood plains of the Northern Region, which, however, imply the need for substantial financial resources and changes in the Forest Code in force today.

Thus, the upland rice is the alternative to meet the needs of Brazilian consumers and generate exportable surpluses, for its potential growth exceeding 50 million hectares for expansion, especially in climatically favored regions (Tocantins, northern Goiás, Pará, northern Mato Grosso, Maranhão). However, in the states of Paraná, São Paulo, Minas Gerais and Bahia, where the occurrence of dry periods in January and February (dry spells) is common, upland rice crops would be possible only through the adoption of high-technology production systems, with supplemental sprinkler irrigation. This system requires cultivars carrying some basic features such as: low/intermediate height, narrow, short and straight leaves, short cycle, lodging resistance, high yield potential, fine-long grain, good milling yield and good cooking behavior (Fornasieri Filho \& Fornasieri, 2006), as well as adaptation of cultural practices that make the system more efficient. In this respect, nitrogen, considered as the main factor limiting the productivity of rice under conditions of adequate water availability (Fageria \& Barbosa Filho, 2001), deserves special attention.

Nitrogen is an important component of numerous organic compounds such as amino acids, nucleic acids and proteins (Epstein, 1975). It is one of the main factors involved in productivity (Fageria \& Barbosa Filho, 2001) and in improving the nutritional quality of rice grain (Mingotte et al., 2012) for positively affecting the protein fraction of glutelin, rich in essential amino acids (Ferraz Junior. et al. 1997). This nutrient, when overproduced in the vegetative stage and between the neck-node differentiation and spikelet differentiation stages, absorbed and metabolized, induces increased levels of protein instead of carbohydrates, resulting in excessive growth of shoots, affecting negatively the root system, degree of lodging, spikelet fertility and lowering the resistance of plants to water deficiency (Marschner, 1986; Matsushima, 1980).

The beneficial effects of nitrogen occur by influencing yield components: number of panicles per unit area, number of spikelets per panicle, spikelet fertility and 1000 grain mass, and panicle length (Fageria \& Baligar, 2001; Fageria \& Barbosa Filho, 2001), which are controlled by genetic factors of the plant and environmental factors (Freitas et al., 2001).

Genotypes of the same species have different nutritional requirements and tolerances to mineral nutrients (Machado et al., 2001; Zou et al., 2002). In rice, there are frequent variations within species, regarding the use and accumulation of nitrogen and its genetic control (Ferraz Junior et al., 1997; Freitas et al., 2001; Fageria \& Baligar, 2001). These genotypic differences help in the adaptation of species and cultivars to various environmental stress conditions and form the basis for genetic improvement programs. The cultivation of rice genotypes with efficient $\mathrm{N}$ use in combination with correct nitrogen fertilization is a promising strategy for increasing the yield of upland rice, reducing production costs and environmental impacts.

In this context, this study aimed to evaluate the agronomic performance of commercial rice cultivars with different plant characteristics in upland conditions under supplemental sprinkler irrigation and topdress application of nitrogen.

\section{MATERIAL AND METHODS}

The experiment was conducted in Jaboticabal-SP-Brazil in $2006 / 2007$, at $21^{\circ} 14^{\prime} 05^{\prime \prime} \mathrm{S}$ and $48^{\circ} 17^{\prime} 09^{\prime \prime} \mathrm{W}$, with $615 \mathrm{~m}$ 
of altitude. The climate, according to Köeppen classification is considered as a transition zone between regions of $\mathrm{Cwa}$ (mesothermal climate/altitude tropical) and Aw (megathermal climate/tropical wet), with rainy summer and relatively dry winter. The crop was planted in Typic Eutrustox, clayey, A moderate, oxidic kaolinic, mesoferric soil and gently rolling relief (EMBRAPA, 2006). The soil chemical attributes were determined in soil samples from 0-20 cm depth as described by Raij (1987) (Table 1).

The area was previously cultivated with upland rice and prepared by deep plowing and two diskings. The basic fertilization consisted of $300 \mathrm{~kg} \mathrm{ha}^{-1}$ of a 04-20-15 formulation with $0.3 \% \mathrm{Zn}$ and was based on the soil analysis and fertilizer recommendation for upland rice, with sprinkler irrigation for the State of São Paulo with expected yield of 4 ton ha-1 (Cantarella et al., 1996).

The experiment was arranged in a randomized block split-plot design with four replications. The treatments consisted of a combination of 13 rice cultivars in the plots (aromatic type: BRS Aroma, IAC 500; Arborio type: Baldo and Carnaroli; common type: Caiapó, CIRAD 141, BRS Primavera, BRS Curinga, BRS Colosso, IAC 25, IAC 201, IAC 202 and Best 2000) and five doses of nitrogen in the splitplots (0, 40, 80, 120 and $\left.160 \mathrm{~kg} \mathrm{ha}^{-1}\right)$, using ammonium nitrate as a source. Nitrogen was applied as topdressing at the $\mathrm{R}_{1}$ stage (panicle differentiation) of the Counce et al. (2000) scale, referred as the spikelet differentiation (1.5 to $2 \mathrm{~cm}$ long in the panicle primordial stage), according to recommendations of Matsushima (1979).

Each experimental unit was represented by eight rows, with $6 \mathrm{~m}$ length, spaced by $0.4 \mathrm{~m}$, and seeding rate of 200 viable seeds per $\mathrm{m}^{2}$; using the center six rows for evaluations.

The weed control was made in pre-emergence, using a pendimethalin-based herbicide $\left(1.5 \mathrm{~kg}\right.$ a.i. $\left.\mathrm{ha}^{-1}\right)$ and in postemergence with a cyhalofop butyl ether-based herbicide (270 g a.i. ha $\left.{ }^{-1}\right)$, in addition to mechanical control measures.

The irrigation was applied by conventional sprinkler system. The irrigation management was carried out by readings on tensiometers (gauge type) installed at depths of 10 and $20 \mathrm{~cm}$ and the soil water retention curves, with irrigation applied when the tensiometer indicated values corresponding to $0.07 \mathrm{MPa}$ (Fornasieri Filho \& Fornasieri, 2006).

At the end of the cycle, when $2 / 3$ of caryopses, in $50 \%$ of panicles, were hard and the remaining were medium- hard, 15 panicles were randomly picked per splitplot, and stored in a cold chamber. Then, the panicles of the center rows were harvested.

All plants on $0.50 \mathrm{~m}$ of one of the center rows were sampled (low cutting) to determine the dry matter of grain and straw (culms and straw). Threshing was done mechanically and drying was under natural conditions.

The evaluations performed during the experimental period are described bellow.

\section{Phenological characteristics of the plant}

Plant height $(\mathrm{cm})$ was determined by averaging ten plants per experimental unit, measured from ground level to the tip of the tallest panicle, during the dough stage. The lodging degree was determined by visual evaluation performed immediately before the final harvest, using a grading scale, where: $1=$ no lodging; $3=$ up to $25 \%$ lodged plants; $5=25-50 \%$ lodged plants; $7=50-75 \%$ of lodged plants; $9=75$ to $100 \%$ of lodged plants.

\section{Components of plant production and grain yield $\left(\mathrm{kg} \mathrm{ha}^{-1}\right)$}

The number of panicles per area was counted on each plant in $1 \mathrm{~m}$ of the center rows at harvest of each experimental unit. The total number of spikelets per panicle was counted on the 15 plants collected per experimental unit at the final harvest. The number of grains per panicle was obtained by counting the number of filled spikelets contained in the 15 panicles per experimental unit, after separation from unfilled spikelets in an airflow sorter. The spikelet fertility was determined from the ratio between the number of grains per panicle and the number of spikelets per panicle multiplied by 100 .

The 1000-seed mass ( $\mathrm{g}$ ) was determined from eight subsamples of 100 seeds per experimental unit and weighed on a two decimal place balance (Brazil, 1992). The result, in grams, was transformed into $13 \%$ moisture content (wet basis). Panicle length $(\mathrm{cm})$ was measured from the base of the panicle (first node) to the apex spikelet on fifteen panicles per experimental unit. Paddy grain yield was determined after harvest, threshing, blowing and drying of the material collected from the center rows of each experimental unit. After weighing, data were transformed into $\mathrm{kg} \mathrm{ha}^{-1}$ (13\% wet basis). Moisture content in grains was obtained by the oven method, at $105 \pm 3{ }^{\circ} \mathrm{C}$ for 24 hours (Brazil, 1992).

Table 1. Results of soil chemical analysis $(0-20 \mathrm{~cm})$ for the experimental area, in Jaboticabal - SP - Brazil

\begin{tabular}{|c|c|c|c|c|c|c|c|c|c|}
\hline \multirow{2}{*}{$\begin{array}{l}P \text { resin } \\
\mathbf{m g ~ d m}^{-3}\end{array}$} & \multirow{2}{*}{$\begin{array}{l}\text { M.O. } \\
\text { g dm}^{-3}\end{array}$} & \multirow{2}{*}{$\begin{array}{c}\mathrm{pH} \\
\mathrm{CaCl}_{2}\end{array}$} & $\mathbf{K}$ & $\mathbf{C a}$ & Mg & $\mathrm{H}+\mathrm{Al}$ & SB & $\mathbf{T}$ & \multirow{2}{*}{$\begin{array}{l}\mathrm{V} \\
\%\end{array}$} \\
\hline & & & & & \multicolumn{2}{|c|}{$\mathrm{mmol}_{\mathrm{c}} \mathrm{dm}^{-3}$} & & & \\
\hline 52 & 40 & 5.8 & 1.4 & 40 & 22 & 20 & 63.4 & 83.4 & 76 \\
\hline
\end{tabular}




\section{Nitrogen}

For leaf $\mathrm{N}$ determination, leaves were sampled as described by Cantarella et al. (1996) and, in the laboratory, according to Battaglia et al. (1983)

\section{Statistical Analysis}

The individual analyses of variance were performed using the Statistical Analysis System - Stats. The Tukey test at $5 \%$ was applied to compare means between cultivars using the complex variances calculated within each nitrogen rate. The t-test at $5 \%$ probability was used to assess the significance of polynomial regressions, regarding the effects of the applied nitrogen.

\section{RESULTS AND DISCUSSION}

Plant height was positively influenced by the interaction rice cultivar $\mathrm{x}$ nitrogen fertilization. Regardless of N rate, the cultivars Caiapó, IAC 25 and BRS Primavera had the highest plant heights and BEST 2000, IAC 202 and IAC 500, the lowest plant heights. For most cultivars, nitrogen topdressing increased plant height linearly, except for IAC 201, Cirad 141, BRS Curinga and IAC 500, whose greatest heights were achieved at the rates 125 , 124, 160 and $133 \mathrm{~kg} \mathrm{~N} \mathrm{ha}^{-1}$, respectively, whereas the Arborio cultivars (Baldo and Carnaroli) showed no detectable influence of nitrogen on this biometric component (Table 2). Arf et al. (2003) and Boldieri et al.
(2010) also reported the influence of nitrogen fertilization on increasing plant height in rice. According to Furlani (2004), adequate supply of $\mathrm{N}$ causes changes in plant morphology, balance of shoot/root ratio and increase in length, width and thickness of leaves, causing, when excessive, the excessive growth of shoots at the expense of roots, favoring lodging. These effects are probably related to hormonal balance.

There was no occurrence of lodging among the cultivars. This may have occurred because the nitrogen has been applied at the spikelet differentiation stage, not interfering with the significant growth in plant height (Matsushima, 1979; Fornasieri Filho \& Fornasieri, 2006). Mauad et al. (2003) reported that there was no influence of $\mathrm{N}$ on lodging of cultivar IAC 202, under sprinkler irrigation. Marschner (1986) discussed that excessive doses of $\mathrm{N}$ applied at the stage when vegetative growth become reproductive structures, $R_{0}$ stage in the Counce et al. (2000) scale, stimulates the production of phytohormones, particularly auxin, which induces cell division and expansion and increases the elongation of the lower culm internodes and hence plant height. Matsushima (1979) considers that $\mathrm{N}$ should be supplied between 18 and 20 days before flowering, so as not to interfere with the growth of the lower culm internodes and enable the production of plants in which the two or three upper leaves are short, thin and upright, leading to an increased efficiency of utilization of solar radiation to maximize spikelet fertility.

Table 2. Means and regression equations for plant height in rice cultivars as a function of nitrogen application. Jaboticabal-SP-Brazil. $2006 / 2007$

\begin{tabular}{|c|c|c|c|}
\hline Cultivars & Plant height $(\mathrm{cm})$ & Equation & $\mathbf{R}^{2(2)}$ \\
\hline Caiapó & $86.2 \mathrm{a}$ & $Y=0.0725 X+78.8$ & $0.67 * *$ \\
\hline BRS Primavera & $80.2 \mathrm{ab}$ & $Y=0.0481 X+76.3$ & $0.83 *$ \\
\hline IAC 25 & $79.2 \mathrm{ab}$ & $Y=0.1031 X+71.0$ & $0.81 * *$ \\
\hline IAC 201 & $72.4 \mathrm{~b}$ & $Y=-0.0011 X^{2}+0.2476 X+61.4$ & $0.94 * *$ \\
\hline CIRAD 141 & $59.2 \mathrm{c}$ & $Y=-0.0010 X^{2}+0.2481 X+49.1$ & $0.99 * *$ \\
\hline IAC 202 & $44.3 \mathrm{e}$ & $Y=0.0725 X+38.5$ & $0.96 * *$ \\
\hline BRS Curinga & $58.4 \mathrm{c}$ & $Y=-0.0006 X^{2}+0.2485 X+44.6$ & $0.99 * *$ \\
\hline BRS Colosso & $57.8 \mathrm{c}$ & $Y=0.0602 X+52.9$ & $0.85 * *$ \\
\hline BEST 2000 & $45.6 \mathrm{de}$ & $Y=0.0425 X+42.2$ & $0.79 * *$ \\
\hline IAC 500 & $43.5 \mathrm{e}$ & $Y=-0.0006 X^{2}+0.1600 X+36.7$ & $0.94 *$ \\
\hline BRS Aroma & $71.7 \mathrm{~b}$ & $Y=0.1375 X+60.7$ & $1.00 * *$ \\
\hline Baldo & $57.6 \mathrm{c}$ & $Y=58$ & NS \\
\hline Carnaroli & $53.9 \mathrm{~cd}$ & $Y=54$ & NS \\
\hline \multicolumn{4}{|l|}{ F Test ${ }^{(1)}$} \\
\hline Cultivars (C) & $70.87 * *$ & & \\
\hline DMS & 8.5 & & \\
\hline $\mathrm{N}$ rates $(\mathrm{D})$ & $63.27 * *$ & & \\
\hline Interaction $(\mathrm{C} \times \mathrm{D})$ & $1.77 * *$ & & \\
\hline $\mathrm{CV}(\%) \mathrm{C}$ & 12.2 & & \\
\hline $\mathrm{CV}(\%) \mathrm{D}$ & 7.6 & & \\
\hline
\end{tabular}


A significant interaction was found between the studied factors for panicle length. Cultivars BRS Primavera, CIRAD 141, BRS Curinga, BRS Aroma, IAC 500, IAC 202, BEST 2000 and Carnaroli showed linear increase in panicle length with the use of nitrogen fertilizer, while cultivars Caiapó, IAC 25, IAC 201 and BRS Colosso had the longest panicle length at the rates 153, 118, 117 and $118 \mathrm{~kg} \mathrm{~N} \mathrm{ha}^{-1}$, respectively, but the cultivar Baldo was not affected (Table 3). Buzetti et al. (2006) found a linear increase of panicle length and number of spikelets per panicle with $\mathrm{N}$ topdressing.

There was a significant interaction between cultivars and $\mathrm{N}$ rates for the total $\mathrm{N}$ content in the leaf-flag at flowering. BRS Primavera, IAC 201, IAC 202, BRS Curinga, BRS Colosso, BEST 2000, IAC 500, BRS Aroma and Carnaroli fit the model of positive linear equation, and IAC 25, CIRAD 141 and Baldo fit the quadratic equation, with the rates 134, 107 and $96 \mathrm{~kg} \mathrm{~N} \mathrm{ha}^{-1}$, respectively (Table 4). Boldieri et al. (2010) applied different nitrogen rates to the cultivars BRS Primavera, IAC 202, Caiapó, BRS Carisma and Confiança, at the spikelet differentiation stage, and found that, the total leaf $\mathrm{N}$ content increased with increasing nitrogen rates. Although the contents are different among cultivars, the average is above the range considered as adequate by Cantarella et al. (1996).

There was a significant interaction between the studied factors for the influence of nitrogen topdressing on the rice yield components: number of panicles per area, total number of spikelets per panicle and spikelet fertility, with exception of 1000-seed mass.

Cultivars Caiapó, BRS Primavera, CIRAD 141, BRS Curinga, BRS Colosso, IAC 202, BEST 2000, IAC 500 and Carnaroli showed linear increase of number of panicles per area with the $\mathrm{N}$ rates, while IAC 25, IAC 201, BRS Aroma and Baldo, were not influenced by the nitrogen fertilization (Table 5). Stone et al. (1999) evaluated the performance of different rice genotypes with supplemental irrigation and also observed a positive rice response to nitrogen fertilization on the number of panicles per $\mathrm{m}^{2}$ and number of grains per panicle.

The nitrogen fertilization increased the total number of spikelets per panicle, except for cultivars Baldo, Carnaroli and IAC 500. Cultivars IAC 201, BRS Colosso and BRS Aroma had the largest number of spikelets per panicle at the rates 107,123 and $128 \mathrm{~kg} \mathrm{~N} \mathrm{ha}^{-1}$, respectively (Table 6). The positive effect of nitrogen was due to its greater availability in the period that the spikelets initiated differentiation in the panicle, in its early development (Fornasieri Filho \& Fornasieri, 2006). The influence of N on the increase of this yield component was also observed by Boldieri et al. (2010).

The spikelet fertility of cultivars Caiapó, CIRAD 141, BRS Curinga, BRS Colosso, IAC 201, IAC 202 and Carnaroli was not affected by the nitrogen topdressing; Baldo and 500 IAC responded positively and linearly with increased rates. BRS Primavera, BRS Aroma, IAC

Table 3. Means and regression equations for panicle length of rice cultivars as a function of nitrogen application. Jaboticabal - SP Brazil. 2006/2007

\begin{tabular}{|c|c|c|c|}
\hline Cultivars & Panicle length (cm) & Equation & $\mathbf{R}^{2(2)}$ \\
\hline Caiapó & $22.3 \mathrm{~cd}$ & $Y=-0.0001 X^{2}+0.0429 X+20.3$ & $0.96^{*}$ \\
\hline BRS Primavera & $22.5 \mathrm{~cd}$ & $Y=0.0274 X+20.4$ & $0.65 * *$ \\
\hline IAC 25 & $20.5 \mathrm{~d}$ & $Y=-0.0005 X^{2}+0.118 X+15.8$ & $0.98 *$ \\
\hline IAC 201 & $25.2 \mathrm{~b}$ & $Y=-0.0005 X^{2}+0.1172 X+20.4$ & $0.99 * *$ \\
\hline CIRAD 141 & $20.8 \mathrm{~cd}$ & $Y=0.0173 X+19.5$ & $0.89 * *$ \\
\hline IAC 202 & $21.7 \mathrm{~cd}$ & $Y=0.0555 X+17.3$ & $0.97 * *$ \\
\hline BRS Curinga & $20.7 \mathrm{~cd}$ & $Y=0.0235 X+18.8$ & $0.97 * *$ \\
\hline BRS Colosso & $21.6 \mathrm{~cd}$ & $Y=-0.0003 X^{2}+0.0709 X+18.8$ & $0.72 *$ \\
\hline BEST 2000 & $45.6 \mathrm{a}$ & $Y=0.0425 X+42.2$ & $0.79 * *$ \\
\hline IAC 500 & $20.4 \mathrm{~d}$ & $Y=0.02625 X+18.4$ & $0.76^{* *}$ \\
\hline BRS Aroma & $23.1 \mathrm{bc}$ & $Y=0.0648 X+17.9$ & $0.97 * *$ \\
\hline Baldo & $14.9 \mathrm{e}$ & $\mathrm{Y}=58$ & NS \\
\hline Carnaroli & $15.9 \mathrm{e}$ & $Y=0.0181 X+14.4$ & $0.69 * *$ \\
\hline \multicolumn{4}{|l|}{ F Test ${ }^{(1)}$} \\
\hline Cultivars (C) & $232.78 * *$ & & \\
\hline DMS & 2.4 & & \\
\hline $\mathrm{N}$ rates $(\mathrm{D})$ & $81.85^{* *}$ & & \\
\hline Interaction $(\mathrm{C} \times \mathrm{D})$ & $2.14 * *$ & & \\
\hline $\mathrm{CV}(\%) \mathrm{C}$ & 9.54 & & \\
\hline $\mathrm{CV}(\%) \mathrm{D}$ & 7.44 & & \\
\hline
\end{tabular}

Rev. Ceres, Viçosa, v. 60, n.1, p. 086-095, jan/fev, 2013 
25 and BEST 2000 showed maximum fertility at the rates 64, 110, 124 and $126 \mathrm{~kg} \mathrm{~N} \mathrm{ha}^{-1}$, respectively (Table 7). These results demonstrate the correct time of nitrogen application in agreement with the recommendations of Matsushima (1979): N should be applied, preferably after the spikelet differentiation, as it reduces spikelet

Table 4. Means and regression equations for total $\mathrm{N}$ content in leaf of rice cultivars as a function of nitrogen application. Jaboticabal - SP - Brazil. 2006/2007

\begin{tabular}{|c|c|c|c|}
\hline Cultivars & Total leaf $\mathbf{N}\left(\mathrm{g} \mathrm{kg}^{-1}\right)$ & Equation & $\mathbf{R}^{2(2)}$ \\
\hline Caiapó & 44 cde & $Y=44$ & NS \\
\hline BRS Primavera & $47 \mathrm{bc}$ & $Y=0.1213 X+37.7$ & $0.96 * *$ \\
\hline IAC 25 & $42 \mathrm{efg}$ & $Y=-0.0009 X^{2}+0.2409 X+31.9$ & $0.83 * *$ \\
\hline IAC 201 & $44 \mathrm{efg}$ & $Y=0.0256 X+40.4$ & $0.83 *$ \\
\hline CIRAD 141 & $39 \mathrm{~g}$ & $Y=-0.0013 X^{2}+0.2795 X+29.6$ & $0.97 * *$ \\
\hline IAC 202 & 45 cde & $Y=0.09063 X+37.3$ & $0.97 * *$ \\
\hline BRS Curinga & $43 \mathrm{def}$ & $Y=0.0563 X+38.9$ & $0.70^{* *}$ \\
\hline BRS Colosso & $39 \mathrm{~g}$ & $Y=0.1163 X+30.1$ & $0.99 * *$ \\
\hline BEST 2000 & $40 \mathrm{fg}$ & $Y=0.075 X+33.8$ & $0.97 * *$ \\
\hline IAC 500 & $52 \mathrm{a}$ & $Y=0.0344 X+49.7$ & $0.79 *$ \\
\hline BRS Aroma & $28 \mathrm{~h}$ & $Y=0.0725 X+22.3$ & $0.95 * *$ \\
\hline Baldo & $47 \mathrm{~cd}$ & $Y=-0.00203 X^{2}+0.3888 X+35.3$ & $0.84 * *$ \\
\hline Carnaroli & $50 \mathrm{ab}$ & $Y=0.1281 X+40.4$ & $0.97 * *$ \\
\hline \multicolumn{4}{|l|}{ F Test ${ }^{(1)}$} \\
\hline Cultivars (C) & $69.27 * *$ & & \\
\hline DMS & 3.7 & & \\
\hline $\mathrm{N}$ rates $(\mathrm{D})$ & $82.20 * *$ & & \\
\hline Interaction $(\mathrm{C} \times \mathrm{D})$ & $10.64 * *$ & & \\
\hline $\mathrm{CV}(\%) \mathrm{C}$ & 7.64 & & \\
\hline $\mathrm{CV}(\%) \mathrm{D}$ & 6.69 & & \\
\hline
\end{tabular}

Table 5. Means and regression equations for number of panicles per square meter in rice cultivars as a function of nitrogen application. Jaboticabal - SP - Brazil. 2006/2007

\begin{tabular}{|c|c|c|c|}
\hline Cultivars & Panicles per $\mathbf{m}^{2}$ & Equation & $\mathbf{R}^{2(2)}$ \\
\hline Caiapó & $282 \mathrm{bc}$ & $Y=0.4194 X+248$ & $0.78 * *$ \\
\hline BRS Primavera & $315 \mathrm{ab}$ & $Y=0.2375 X+296$ & $0.43^{*}$ \\
\hline IAC 25 & $206 \mathrm{ef}$ & $Y=206$ & NS \\
\hline IAC 201 & $238 \mathrm{de}$ & $\mathrm{Y}=238$ & NS \\
\hline CIRAD 141 & $250 \mathrm{~cd}$ & $Y=0.6044 X+202$ & $0.95 * *$ \\
\hline IAC 202 & $263 \mathrm{~cd}$ & $Y=0.3819 X+233$ & $0.61 * *$ \\
\hline BRS Curinga & $271 \mathrm{~cd}$ & $Y=0.5431 X+228$ & $0.73 * *$ \\
\hline BRS Colosso & $256 \mathrm{~cd}$ & $Y=0.3038 X+231$ & $0.84 *$ \\
\hline BEST 2000 & $324 \mathrm{a}$ & $Y=0.7925 X+260$ & $0.93 * *$ \\
\hline IAC 500 & $209 \mathrm{ef}$ & $Y=0.8675 X+139$ & $0.97 * *$ \\
\hline BRS Aroma & $316 a b$ & $Y=316$ & NS \\
\hline Baldo & $255 \mathrm{~cd}$ & $\mathrm{Y}=255$ & NS \\
\hline Carnaroli & $183 \mathrm{f}$ & $Y=0.6950 X+127$ & $0.99 * *$ \\
\hline \multicolumn{4}{|l|}{ F Test ${ }^{(1)}$} \\
\hline Cultivars (C) & $32.76^{* *}$ & & \\
\hline DMS & 38.3 & & \\
\hline $\mathrm{N}$ rates $(\mathrm{D})$ & $41.06^{* *}$ & & \\
\hline Interaction (C x D) & $1.95 * *$ & & \\
\hline $\mathrm{CV}(\%) \mathrm{C}$ & 13.2 & & \\
\hline $\mathrm{CV}(\%) \mathrm{D}$ & 12.0 & & \\
\hline
\end{tabular}


sterility, because the two or three upper leaves remain erect, providing a more efficient use of the photosynthetically active radiation. The lowest fertility of BEST 2000 may be due to its larger number of panicles per area and larger number of spikelets per panicle, which increases competition for

Table 6. Means and regression equations for the total number of spikelets per panicle in rice cultivars as a function of nitrogen application. Jaboticabal - SP - Brazil. 2006/2007

\begin{tabular}{|c|c|c|c|}
\hline Cultivars & Total number of spikelets per panicle & Equation & $\mathbf{R}^{2(2)}$ \\
\hline Caiapó & $171 \mathrm{ab}$ & $Y=0.2056 X+155$ & $0.79 * *$ \\
\hline BRS Primavera & $129 \mathrm{c}$ & $Y=0.2237 X+111$ & $0.83 * *$ \\
\hline IAC 25 & 98 de & $Y=0.2275 X+80$ & $0.74 * *$ \\
\hline IAC 201 & $174 \mathrm{a}$ & $Y=-0.0033 X^{2}+0.7049 X+149$ & $0.76^{*}$ \\
\hline CIRAD 141 & $166 \mathrm{ab}$ & $Y=0.3956 X+134$ & $0.93 * *$ \\
\hline IAC 202 & $156 \mathrm{~b}$ & $Y=0.4406 X+121$ & $0.92 * *$ \\
\hline BRS Curinga & $92 \mathrm{e}$ & $Y=0.3306 X+65$ & $0.75^{* *}$ \\
\hline BRS Colosso & $127 \mathrm{c}$ & $Y=-0.0043 X^{2}+1.061 X+84$ & $0.93 * *$ \\
\hline BEST 2000 & $157 \mathrm{~b}$ & $Y=0.8068 X+92$ & $0.93 * *$ \\
\hline IAC 500 & $113 \mathrm{~cd}$ & $\mathrm{Y}=113$ & NS \\
\hline BRS Aroma & $117 \mathrm{c}$ & $Y=-0.0035 X^{2}+0.8999 X+78$ & $0.99 * *$ \\
\hline Baldo & $66 \mathrm{f}$ & $Y=66$ & NS \\
\hline Carnaroli & $71 \mathrm{f}$ & $\mathrm{Y}=71$ & NS \\
\hline \multicolumn{4}{|l|}{ F Test ${ }^{(1)}$} \\
\hline Cultivars (C) & $134.57 * *$ & & \\
\hline DMS & 16.21 & & \\
\hline $\mathrm{N}$ rates $(\mathrm{D})$ & $87.07 * *$ & & \\
\hline Interaction $(\mathrm{C} \times \mathrm{D})$ & $4.37 * *$ & & \\
\hline $\mathrm{CV}(\%) \mathrm{C}$ & 11.49 & & \\
\hline $\mathrm{CV}(\%) \mathrm{D}$ & 12.17 & & \\
\hline
\end{tabular}

Table 7. Means and regression equations for spikelet fertility $(\%)$ in rice cultivars as a function of nitrogen application. Jaboticabal - SP - Brazil. 2006/2007

\begin{tabular}{|c|c|c|c|}
\hline Cultivars & Spikelet fertility (\%) & Equation & $\mathbf{R}^{2(2)}$ \\
\hline Caiapó & $89 \mathrm{bc}$ & $\mathrm{Y}=171$ & NS \\
\hline BRS Primavera & $90 \mathrm{ab}$ & $Y=-0.0003 X^{2}+0.0386 X+90$ & $0.92 * *$ \\
\hline IAC 25 & $90 \mathrm{ab}$ & $Y=-0.0003 X^{2}+0.0747 X+91$ & $0.70^{*}$ \\
\hline IAC 201 & $89 \mathrm{bc}$ & $\mathrm{Y}=174$ & NS \\
\hline CIRAD 141 & $83 \mathrm{~d}$ & $\mathrm{Y}=166$ & NS \\
\hline IAC 202 & $86 \mathrm{~cd}$ & $\mathrm{Y}=156$ & NS \\
\hline BRS Curinga & $93 \mathrm{a}$ & $\mathrm{Y}=92$ & NS \\
\hline BRS Colosso & $91 \mathrm{ab}$ & $\mathrm{Y}=127$ & NS \\
\hline BEST 2000 & $70 \mathrm{e}$ & $Y=-0.0016 X^{2}+0.4022 X+87$ & $0.63 * *$ \\
\hline IAC 500 & $48 \mathrm{f}$ & $Y=0.1087 X+57$ & $0.83^{*}$ \\
\hline BRS Aroma & $89 \mathrm{bc}$ & $Y=-0.0007 X^{2}+0.1544 X+94$ & $0.54 * *$ \\
\hline Baldo & $89 \mathrm{bc}$ & $Y=0.0481 X+94$ & $0.94 * *$ \\
\hline Carnaroli & $88 \mathrm{bc}$ & $\mathrm{Y}=71$ & NS \\
\hline \multicolumn{4}{|l|}{$\mathrm{F}$ Test $^{(1)}$} \\
\hline Cultivars $(\mathrm{C})$ & $333.22 * *$ & & \\
\hline DMS & 3.43 & & \\
\hline $\mathrm{N}$ rates $(\mathrm{D})$ & $20.17 * *$ & & \\
\hline Interaction $(\mathrm{C} \times \mathrm{D})$ & $8.36 * *$ & & \\
\hline $\mathrm{CV}(\%) \mathrm{C}$ & 3.61 & & \\
\hline $\mathrm{CV}(\%) \mathrm{D}$ & 3.84 & & \\
\hline
\end{tabular}

Rev. Ceres, Viçosa, v. 60, n.1, p. 086-095, jan/fev, 2013 
photoassimilates, or even to the more adverse environmental factors in the period between microsporogenesis (pollen grain formation) and

Table 8. Means and regression equations for 1000-seed mass in rice cultivars as a function of nitrogen application. Jaboticabal SP - Brazil. 2006/2007

\begin{tabular}{lc}
\hline Cultivars & $\mathbf{1 0 0 0}$-seed mass (g) \\
\hline Caiapó & $28 \mathrm{~d}$ \\
BRS Primavera & $25 \mathrm{ef}$ \\
IAC 25 & $35 \mathrm{c}$ \\
IAC 201 & $25 \mathrm{ef}$ \\
CIRAD 141 & $26 \mathrm{de}$ \\
IAC 202 & $23 \mathrm{f}$ \\
BRS Curinga & $24 \mathrm{f}$ \\
BRS Colosso & $24 \mathrm{f}$ \\
BEST 2000 & $20 \mathrm{~g}$ \\
IAC 500 & $19 \mathrm{~g}$ \\
BRS Aroma & $23 \mathrm{f}$ \\
Baldo & $39 \mathrm{~b}$ \\
Carnaroli & $41 \mathrm{a}$ \\
\hline F Test ${ }^{(1)}$ & \\
Cultivars (C) & $267.18^{* *}$ \\
DMS & 2.1 \\
N rates (D) & $1.06^{\mathrm{NS}}$ \\
Interaction (C x D) & $1.06^{\mathrm{NS}}$ \\
CV(\%) C & 7.05 \\
CV(\%) D & 6.45 \\
\hline
\end{tabular}

(I) NS = non significant; $* *=$ significant at $1 \%$ probability level by the $\mathrm{t}$ test, respectively. anthesis, since its cycle is longer than the others. In IAC 500, there was high incidence of the leaf disease brown spot (Helminthosporium oryzae), appearing from the panicle initiation and causing spikelet sterility.

The reduction in spikelet fertility, after reaching the point of maximum in the cultivars mentioned above, may have occurred by the increased competition for photoassimilates during the fertilization and microsporogenesis (Fornasieri Filho \& Fornasieri, 2006). Boldieri et al. (2010) consider that the occurrence of reduced sterility under high $\mathrm{N}$ rates is an important criterion in selecting rice genotypes responsive to the nutrient.

Differences were detected for the 1000-seed mass exclusively on the basis of cultivars (Table 8), with no influence of the nitrogen application, which agrees with the results of Stone et al. (1999), Arf et al. (2003), Farinelli et al. (2004) and Boldieri et al. (2010). The performance of this component can be influenced by the cultivar, the time of $\mathrm{N}$ application and environmental factors. Regarding the varietal influence, cultivars Carnaroli, Baldo and IAC 25 had the highest mass per 1 grain unit, while BEST 2000 and IAC 500 had the lowest mass per 1 grain unit. The high incidence of leaf disease in IAC 500 has probably interfered with grain-setting. The performance observed was because this yield component is a stable genetic characteristic, as it depends on the shell size (Fornasieri Filho \& Fornasieri, 2006).

Table 9. Means and regression equations for grain yield in rice cultivars as a function of nitrogen application. Jaboticabal - SP - Brazil. 2006/2007

\begin{tabular}{llll}
\hline Cultivars & Grain yield $\left(\mathbf{k g ~ h a}^{-1}\right)$ & Equation & $\mathbf{R}^{\mathbf{2}(\mathbf{2})}$ \\
\hline Caiapó & $4.413 \mathrm{ab}$ & $\mathrm{Y}=-0.0638 \mathrm{X}^{2}+23.15 \mathrm{X}+3.174$ & $1.00^{* *}$ \\
BRS Primavera & $4.511 \mathrm{a}$ & $\mathrm{Y}=-0.1553 \mathrm{X}^{2}+40.44 \mathrm{X}+2.767$ & $0.96^{* *}$ \\
IAC 25 & $3.830 \mathrm{~cd}$ & $\mathrm{Y}=-0.1011 \mathrm{X}^{2}+32.32 \mathrm{X}+2.224$ & $0.98^{* *}$ \\
IAC 201 & $3.388 \mathrm{de}$ & $\mathrm{Y}=-0.0897 \mathrm{X}^{2}+24.91 \mathrm{X}+2.257$ & $0.98^{* *}$ \\
CIRAD 141 & $\mathrm{Y}=-0.1404 \mathrm{X}^{2}+44.20 \mathrm{X}+1.941$ & $0.99^{* *}$ \\
IAC 202 & $3.129 \mathrm{ef}$ & $\mathrm{Y}=-0.0880 \mathrm{X}^{2}+35.21 \mathrm{X}+2.609$ & $1.00^{* *}$ \\
BRS Curinga & $4.583 \mathrm{a}$ & $\mathrm{Y}=-0.0997 \mathrm{X}^{2}+30.78 \mathrm{X}+1.185$ & $0.99^{* *}$ \\
BRS Colosso & $2.690 \mathrm{fg}$ & $\mathrm{Y}=-0.1120 \mathrm{X}^{2}+31.81 \mathrm{X}+1.671$ & $0.98^{* *}$ \\
BEST 2000 & $3.140 \mathrm{ef}$ & $\mathrm{Y}=-0.0865 \mathrm{X}^{2}+27.84 \mathrm{X}+2.254$ & $0.99^{* *}$ \\
IAC 500 & $3.652 \mathrm{~cd}$ & $\mathrm{Y}=810$ & $\mathrm{NS}$ \\
BRS Aroma & $810 \mathrm{~h}$ & $\mathrm{Y}=-0.0770 \mathrm{X}^{2}+27.35 \mathrm{X}+2.533$ & $0.90^{* *}$ \\
Baldo & $3.982 \mathrm{bc}$ & $\mathrm{Y}=-0.1288 \mathrm{X}^{2}+25.76 \mathrm{X}+1.930$ & $0.81^{* *}$ \\
Carnaroli & $2.755 \mathrm{fg}$ & $\mathrm{Y}=-0.0616 \mathrm{X}^{2}+20.16 \mathrm{X}+1.249$ & $0.95^{*}$ \\
\hline F Test & $2.271 \mathrm{~g}$ & &
\end{tabular}

\begin{tabular}{ll}
\hline F Test & $(1)$ \\
Cultivars (C) & $107.42^{* *}$ \\
DMS & 507.4 \\
N rates (D) & $365.75^{* *}$ \\
Interaction (C x D) & $6.01^{* *}$ \\
CV $(\%)$ C & 13.6 \\
CV $(\%)$ D & 10.1
\end{tabular}

(1) $* *=$ significant at $1 \%$ probability by the $\mathrm{F}$ test. ${ }^{(2)} \mathrm{NS}=$ non significant, $*$ and $* *=$ significant at 5 and $1 \%$ probability level by the $\mathrm{t}$ test, respectively. 
Table 10. Means and regression equations for harvest index in rice cultivars as a function of nitrogen application. Jaboticabal - SP Brazil. 2006/2007

\begin{tabular}{|c|c|c|c|}
\hline Cultivars & Harvest index & Equation & $\mathbf{R}^{2(2)}$ \\
\hline $\begin{array}{l}\text { Caiapó } \\
\end{array}$ & 27.4 bcde & $Y=27.4$ & NS \\
\hline BRS Primavera & $30.4 \mathrm{abc}$ & $Y=-0.0014 X^{2}+0.2705 X+19.7$ & $0.73 * *$ \\
\hline IAC 25 & $32.3 \mathrm{ab}$ & $Y=-0.0012 X^{2}+0.2348 X+25.3$ & $0.83^{*}$ \\
\hline IAC 201 & $26.0 \mathrm{cde}$ & $Y=0.0698 X+20.4$ & $0.72 * *$ \\
\hline CIRAD 141 & $22.9 \mathrm{e}$ & $Y=-0.0009 X^{2}+0.2380 X+12.9$ & $0.91 * *$ \\
\hline IAC 202 & $35.2 \mathrm{a}$ & $\mathrm{Y}=35.2$ & NS \\
\hline BRS Curinga & $21.9 \mathrm{e}$ & $Y=0.0674 X+16.5$ & $0.84 * *$ \\
\hline BRS Colosso & $29.2 \mathrm{bcd}$ & $\mathrm{Y}=29.2$ & NS \\
\hline BEST 2000 & $35.05 \mathrm{a}$ & $Y=0.0768 X+28.9$ & $0.53 * *$ \\
\hline IAC 500 & $12.9 \mathrm{f}$ & $\mathrm{Y}=12.9$ & NS \\
\hline BRS Aroma & $30.4 \mathrm{abc}$ & $Y=-0.0013 X^{2}+0.2711 X+21.1$ & $0.48^{*}$ \\
\hline Baldo & $32.0 \mathrm{ab}$ & $Y=-0.0020 X^{2}+0.2528 X+30.7$ & $0.70 * *$ \\
\hline Carnaroli & $24.4 \mathrm{de}$ & $Y=-0.0009 X^{2}+0.1827 X+18.4$ & $0.63 *$ \\
\hline \multicolumn{4}{|l|}{ F Test ${ }^{(1)}$} \\
\hline Cultivars (C) & $30.36 * *$ & & \\
\hline DMS & 5.6 & & \\
\hline $\mathrm{N}$ rates $(\mathrm{D})$ & $23.83 * *$ & & \\
\hline Interaction (C x D) & $3.16^{* *}$ & & \\
\hline $\mathrm{CV}(\%) \mathrm{C}$ & 18.1 & & \\
\hline $\mathrm{CV}(\%) \mathrm{D}$ & 16.9 & & \\
\hline
\end{tabular}

(1) $* *=$ significant at $1 \%$ probability by the $\mathrm{F}$ test. ${ }^{(2)} \mathrm{NS}=$ non significant, $*$ and $* *=$ significant at 5 and $1 \%$ probability level by the $\mathrm{t}$ test, respectively.

Overall, the cultivars BRS Primavera, Caiapó and IAC 202 stood out with the highest yields; IAC 500 with reduced grain yield (caused by the high incidence of brown spot); and the Arborio types (Baldo and Carnaroli) with intermediate yields. All cultivars, except IAC 500, showed a quadratic response to nitrogen topdressing, with the highest yields with $\mathrm{N}$ rates above $130 \mathrm{~kg} \mathrm{ha}^{-1}$, except for Baldo, with $100 \mathrm{~kg} \mathrm{~N} \mathrm{ha}^{-1}$ (Table 9). Grain yield is controlled by a large number of genes and depends on the interaction of the yield components and panicle length (Yoshida, 1981). Stone et al. (1999), working with nitrogen topdressing and supplemental sprinkler irrigation, obtained the maximum rice yield of $5523 \mathrm{~kg} \mathrm{ha}^{-1}$ with $113 \mathrm{~kg} \mathrm{~N} \mathrm{ha}^{-1}$. In general, the increase in yield with increasing nitrogen rates occurred because of the increased number of panicles per unit area, number of spikelets per panicle and spikelet fertility, which was also reported by Buzetti et al. (2006).

The harvest indices (HI) ranged between $12.9 \%$ (IAC 500, with high sterility rate) and 35\% (BEST 2000 and IAC 202, both plants of the modern type). The nitrogen increased linearly this physiological component in IAC 201, BRS MG Curinga and Best 2000. The topdressed nitrogen influenced negatively this component in the cultivars Baldo, IAC 25, Carnaroli, BRS Aroma, BRS Primavera and CIRAD 141, starting from the rates 63, 99, 101, 104, 118 and $132 \mathrm{~kg} \mathrm{~N} \mathrm{ha}^{-1}$, respectively (Table 10). This performance reflects the imbalance between the production of total dry matter and grain. Donald \& Hamblim (1976) discussed that the increase in the yield potential of modern cereal cultivars (rice, corn, wheat, sorghum and oat) is related to their higher HI, with little variation in biological productivity in comparison with the traditional cultivars. The HI of traditional rice cultivars is around $30 \%$ and that of the modern cultivars is around 50\% (Mae, 1997). The harvest index represents the conversion efficiency of synthesized products into economically important materials, in this case, the grains, and is determined by both the genotype and the environment (Pereira \& Machado, 1987).

\section{CONCLUSIONS}

The cultivars BRS Primavera, Caiapó and IAC 202 stood out with the highest grain yields, while Baldo, Carnaroli, BRS Curinga and IAC 500 had the lowest yields.

The cultivars IAC 202 and BEST 2000 showed the highest harvest indices, which was reduced with increasing nitrogen fertilization.

Topdressed nitrogen increased, in general, the panicle length, panicle number per unit area, the number of spikelets per panicle and spikelet fertility.

The 1000-seed mass was influenced by genotype; but $\mathrm{N}$ fertilization did not affect this variable. 


\section{REFERENCES}

Arf O, Rodrigues RAF, Crusciol CAC, Sá ME \& Buzetti S (2003) Soil management and nitrogen fertilization for sprinkler irrigated upland rice cultivars. Scientia Agrícola, 60:345-352.

Bataglia OG, Furlani AMC, Teixeira JPF, Furlani PR \& Gallo JR (1983) Métodos de análises químicas de plantas. Campinas, Instituto Agronômico. 48p.

Boldieri FM, Cazetta D \& Fornasieri Filho D (2010) Adubação nitrogenada em cultivares de arroz de terras altas. Revista Ceres, 57:421-428.

Brasil. Ministério da Agricultura e Reforma Agrária (1992) Regras para análise de sementes. Brasília, SNAD/CLAV, 365p.

Buzetti S, Bazanini GC, Freitas JG, Andreotti M, Arf O, Sá ME \& Meira FA (2006) Resposta de cultivares de arroz a doses de nitrogênio.e do regulador de crescimento cloreto de clormequat. Pesquisa Agropecuária Brasileira, 41:1731-1737.

Cantarella H, Raij B van \& Camargo CEO (1996) Cereais. In: Raij B van.; Cantarella H, Quaggio JA \& Furlani AMC (Eds.) Recomendações de calagem e adubação para o Estado de São Paulo, $2^{\mathrm{a}}$ ed. Campinas, Instituto Agronômico de Campinas. p.43-73.

Conab - Companhia Nacional de Abastecimento (2011) Acompanhamento da safra brasileira. Available at: <http:// www.conab.gov.br>. Accessed on: 11 de fevereiro de 2011.

Counce PA, Keisling TC \& Mitchel, AJ (2000) A uniform, objective, and adaptative system for expressing rice development. Crop Science, 40:436-443.

Donald DM \& Hamblim J (1976) The biological yield and harvest index of cereals as agronomic and plant breeding criteria. Advances in Agronomy, 28:361-405.

Empresa Brasileira de Pesquisa Agropecuária - Embrapa (2006) Sistema Brasileiro de Classificação de Solos. 2a ed. Rio de Janeiro, Embrapa Solos. 412p.

Epstein EA (1975) Aquisição de nitrogênio. In: Nutrição mineral de plantas: princípios e perspectivas. Malavolta E (Trad.) Rio de Janeiro, Livros Técnicos e Científicos, São Paulo, EDUSP. p. 213-234.

Farinelli R, Penariol FG, Fornasieri Filho D \& Bordin L (2004) Características agronômicas de arroz de terras altas sob plantio direto e adubação nitrogenada e potássica. Revista Brasileira de Ciência do Solo, 28:447-454.

Fageria NK \& Baligar VC (2001) Lowland rice response to nitrogen fertilization. Communication Soil Science Plant Analysis, $32: 1405-1428$

Fageria NK \& Barbosa Filho MP (2001) Nitrogen use efficiency in lowland rice genotypes. Communication Soil Science Plant Analysis, 32:2079-2089

Ferraz Junior ASL, Souza SR, Fernandes MS \& Rossiello ROP (1997) Eficiência de uso de nitrogênio para produção de grão e proteína por cultivares de arroz. Pesquisa Agropecuária Brasileira, 32:435-442.

Fornasieri Filho D \& Fornasieri JL (2006) Manual da cultura do arroz. Jaboticabal, FUNEP. 589p.

Freitas JG, Azzini LE, Cantarella H, Bastos CR, Castro LHSM, Gallo PB \& Felício JC (2001) Resposta de cultivares de arroz irrigado ao nitrogênio. Scientia Agricola, 58:573-579.

Furlani AMC (2004) Nutrição mineral. In: Kerbauy GB (Ed.) Fisiologia vegetal, Rio de Janeiro, Guanabara Koogan. p.40-75.

Machado CTT, Furlani AMC \& Machado AT (2001) Índices de eficiência de variedades locais e melhoradas de milho ao fósforo. Bragantia, 60:225-238.
Mae T (1997) Physiological nitrogen efficiency in rice: nitrogen utilization, photosynthesis, and yield potential. In: Ando T, Fujita K, Mae T, Matsumoto H, Mori S \& Sekiya J. (Eds.) Plant nutrition for sustainable food production and environment. Dordrecht, Kluwer Academic, p.51-60.

Marschner H (1986) Relationship between mineral nutrition and plant diseases and pests. In: Marschner H. (Ed.). Mineral nutrition of higher plants. London, Academic Press. p.369390 .

Matsushima SA (1979) Method for maximizing rice yield on the basis of V-shaped rice cultivation theory. In: Crop science in rice - theory of yield determination and its application. Tokio, Japan Scientific Societies. p.351-364.

Matsushima S (1980) Pratices of stable and high yielding rice cultivation. In: Rice cultivation for the million. Tokio, Japan Scientific Societies. p.141-144.

Mauad M, Crusciol CAC, Grassi Filho H \& Corrêa JC (2003) Nitrogen and silicon fertilization of upland rice. Scientia Agricola, 60:761-765.

Mingotte FLC, Hanashiro, RK \& Fornasieri Filho, D (2012) Características físico-químicas do grão de cultivares de arroz em função da adubação nitrogenada. Semina: Ciências Agrárias, 33:2605-2618.

Pereira AR \& Machado EC (1987) Análise quantitativa do crescimento de comunidades vegetais. Campinas, IAC. 33p.

Raij B van (1987) Análise química do solo para fins de fertilidade. Campinas, Fundação Cargill. 170p.

Stone LF, Silveira PM Moreira JAA \& Yokoyama LP (1999) Adubação nitrogenada em arroz sob irrigação suplementar por aspersão. Pesquisa Agropecuária Brasileira, 34:927-932.

USDA - United States Department of Agriculture (2011). Available at: 〈http://www.fas.usda.gov/psdonline〉. Accessed on: $11 \mathrm{de}$ fevereiro de 2011.

Yokoyama LP, Rucatti EG \& Kluthcouski J (1999) Economia da produção: conjuntura, mercados e custos. In: Vieira NRA, Santos AB \& Sant'Ana EP (Eds.). A cultura do arroz no Brasil. Santo Antônio de Goiás, Embrapa Arroz e Feijão. p.36-57.

Yoshida S (1981) Climatic environment and its influence. In: Fundamentals of rice crop science. Los Baños, IRRI. p.65-110.

Zou C, Li J, Li Z \& Zhang F (2002) Photosynthate distribution in wheat varieties differing in phosphorus efficiency. Communication of Soil Science and Plant Analysis, 33:37673777 . 